\title{
C. S. Lewis's mythopoeia of heaven and earth: implications for the ethical and spiritual formation of multicultural young learners
}

\begin{abstract}
This paper examines C. S. Lewis's perspective of myth or fantasy literature which has mesmerized, and exerted great impact on, young learners' hearts. In a society entrenched in postmodern ideologies, the understanding of what principles govern the construction of ethical and spiritual identity of young learners is often lost. In this context, well written children's literature can be a wonderful avenue where they can restore the value of the ordinary world, escape from the bondage of sinister world, and enhance their sense of supernatural world. This paper argues that these are the major values Lewis held dear in the work of mythopoeia such as The chronicles of Narnia. It also argues that Lewis' fantasy novels for children were primarily his attempt to allow them to experience the mythic quality of good stories, i.e., to savour a more ultimate reality and divine truth through the myriad fantastic images and supernatural imagination.
\end{abstract}

Keywords: C. S. Lewis; mythopoeia; fantasy; spiritual formation; multicultural classroom

\section{Introduction}

In a society entrenched by positivistic or postmodern philosophy, the "shy, persistent, inner voice" (Lewis 1980, 31) of young learners for the supernatural world has rarely been heard in their classroom. I suspect that this phenomenon has much to do with Kreeft's (1994) argument that only a small minority of those who engage in education believes in supernaturalism which has been held up by around 90 percent of the world population. Bolles (2013) offers an ultra-low percentage (i.e., 3 percent) as the number of unbelievers in supernaturalism in the current world. Given that this statistics is true of educational institution, educators warrant a serious soul-searching over why they do not take into account supernaturalism which many students hold dear with their parents. While the choice of atheistic educators needs to be respected, it is imperative that they need to propose and implement a principled and coherent framework of education for those who believe in a supernatural world behind or alongside the natural one. Given that they are an absolute majority of stakeholders in education, it borders on dereliction of duty to center educational system on the argument of a small minority of educators at the expense of the needs of spiritual formation for the majority of students.

This does not necessarily mean that teachers and educators alike should promote a certain religious faith to raise the supernatural awareness in the multicultural classroom. Guiding students who lack essential criteria for discerning among diverse worldviews with relevant religious values has a rightful place in school, but it should be implemented in the spirit of the universal moral virtues which everyone can agree upon. The classroom is a holy ground where every student should be respected and accepted as a worthy human being who has his or her own religious or cultural background. That is one of the bedrock moral principles which have been universally endorsed across religions, cultures, and generations throughout human history. The compendium of these values was called the Tao by $\mathrm{C}$. S. Lewis in The abolition of man (1988). Even though he refers to the Chinese term which means "the Way" or "the Road" for brevity and convenience of argument (435), the Tao owed its resonance to the fact that its roots lie in literature based on multiple traditions and cultures such as the Hindu, Confucian, Egyptian, Babylonian, Indian, Hebrew, Greek, and Christian (Pike 2011). For Lewis, the Tao has connotations of "Natural Law or Traditional Morality or the First 
Principles of Practical Reason or the First Platitudes" (Lewis 1988, 445). In order to avoid misunderstanding, he makes a significant disclaimer in the argument of the Tao. Even though he was a theist, Lewis never attempted "any indirect argument for Theism" more than brought forth "the ultimate platitudes of Practical Reason" as "having absolute validity" in defending moral values and ethical virtues (ibid., 448). Therefore, the Tao, the universal moral principles, may well serve as a bridge to connect the supernatural dimension and teachers' concern about students' moral development or spiritual maturity in the multicultural classroom.

Nonetheless, if the approaches to nurture students' ethical and spiritual formation are too explicit or obvious to the senses of students, they are likely to recoil at these attempts or shy away from them. That is the natural tendency of every human being facing the scene or situation which pushes them to act unlike who they are, let alone coerce them to behave in particular ways. As time wears on, familiarity of these attempts will dull wonder or breed contempt for them. But encourage them to be exposed to some attractive stories of fantasy or myth which are rich in terms of true reality and aesthetic beauty, and their responses or reactions will be as different as poles are apart from each other. Most probably the setting of fantasy or myth puts them off their guard (Martindale 2005, 124), and the stories will "steal past those watchful dragons" of assumptions and prejudices occupied in students' hearts and minds (Lewis 1966, 47).

In light of this argument, this paper examines how C. S. Lewis's perspective on mythopoiea (i.e., myth-making) and his fantasy literature have influenced the ethical and spiritual formation of young learners of English all over the world. He has been well recognized as the author of The chronicles of Narnia, a fantasy series for children. In the world full of materialistic and hedonistic urges and postmodernism perspectives characterized by relative morals and uncertain directions, well written children's literature can be a wonderful avenue where young learners can restore the value of the ordinary world, escape from the bondage of sinister world, and enhance their sense of supernatural world by relating to the actions and feelings of characters in a book. The chronicles has been erected as pillars which our children can depend on in building their own lives and functioned as maps which they can rely on in exploring unchartered territories in their lives.

\section{Myth in literature for young learners}

Lewis believes that literature is a means to the end of teaching "what is useful", honouring "what deserves honour", and appreciating "what is delightful" (1964, 214). All the elements of literature will find their value in serving "the useful, honourable, and delightful". In a sense, literature is a humble servant to cater to the superior needs of human beings. This humility is not foreign to the skills of other professionals such as "a chef, a surgeon, or a scholar" who are supposed to meet the needs of other people (ibid.). Thus, it should not be an excuse to accord a low priority to literature over other disciplines. However, there are many educators and learners who do not think much of literature or imaginative literature because they regard it as a fiction or lie which does not have the element of truth, even though it effectively serves the valuable functions. In other words, literature is a faithful servant, but not a true one, they say. This has been a serious allegation against the nature of literature because as a correlation between the nature and functions of literature begins to break down, literature is likely to be left by the wayside and crumble to dust in the long run. Who doesn't care about literature in the end if it is not true in spite of its valid functions? 
Against the odds, literature has survived the serious allegations and misgivings. People have not deserted literature, instead they have enjoyed it to the fullest sense. Above all, it has particularly been loved by myriad young learners all over the world. What is wrong with the allegation against literature? It is simplistic to say that literature is a lie because it is derived from a fictional world. Just as Wellek and Warren (1956) pointed out in their seminal work on the theory of literature, a fiction is "an artistic, verbal "imitation of life", but it claims to have the element of truth "through the view of life (Weltanschauung) which every artistically coherent work possess", weaving its way in the world of "the probability with which literature must deal" (34). They reached into the very heart of issue by pointing out that "the opposite of 'fiction' is not 'truth' but 'fact' or 'time-and-space existence"' (ibid., 34). In other words, it is true that literature is not fact which is stranger than the fictional world of probability, but it is not true that literature is not truth. Even though literature cannot claim to have truth in the positivist sense which can only be empirically and methodically verified, it can claim to "possess the equivalence of truth" in the alternative sense which "seems some bi-modal or pluri-modal truth" (ibid., 35). In effect, "the truth of literature" takes the form of "the truth in literature" (emphases original, ibid., 34).

Wellek and Warren also pointed out that the alternative sense of truth may further be associated with religious myth whereas the positivist sense of it with philosophical concept and idea. Even though myth has a meaning of "an idea or story that many people believe, but which is not true", it also refers to "an ancient story, especially one invented in order to explain natural or historical events" (Longman Dictionary). If someone says that the narrative in a certain religious text is a myth, he is likely to be lambasted by many adherents in the faith. They will adamantly be opposed to the idea of using the term in describing the narrative. However, looking into the reality of this debate, it is found that the two parties use the term in two different senses. One party claims that myths are nothing more than "lies breathed through silver" (Downing 2002, 147) in the positivist sense whereas the other one argues that "just as speech is invention about objects and ideas, so myth is invention about truth" (Carpenter 1977, 147) in the alternative sense. Tolkien (1966) goes on to call the story-maker of myth or fantasy a "sub-creator" in the sense that he or she makes "a Secondary World" in which readers' mind can participate and experience what is true which is in accord with the laws of that world. The fact that myths have been found in every culture, century, and continent throughout the world bears out the pivotal role which myths have played in the formation of every culture and society. The second meaning of myth (i.e., a true story) has been much older than the first meaning (i.e., a lie) of the word. Myth has always existed, and will exist, with us, forever. As Lief $(2009,324)$ indicates, "even the modern attempt at demythologization has not led to the absence of myth; it has merely produced a vacuum within which new myths have developed." This perennial nature of myths has significant implications for the formation of young learners as well as the one of every culture.

\section{Lewis's myth for young learners}

Fictional literature has significant value in nurturing young learners' artistic and literary imagination by presenting what is true, which influences and moulds their inner formation. In terms of the effect on the formation of children's inner world, however, Lewis made distinction between fantasy literature which is called a "Children's Book" and realistic stories which are called a "Boy's Book" or a "Girl's Book" $(1966,37)$. Against the accusation on the former, i.e., "giving children a false impression of the world they live", Lewis argues that the latter category of children's stories is "far more likely to deceive them" in that children never expect the real world to be like the fantasy stories whereas they expect the real world, say, 
school, to be like the realistic fictions (ibid., 37). The same evaluation goes to the second accusation on fantasy literature, i.e., teaching children "to retreat into a world of wishfulfilment" or "the popular charge of escapism" (ibid.). Yet it should be truer to say that both categories of books arouse and satisfy wishes or longings of children. In the second category of books, children run from the disappointing and humiliating real world to something so close as happy and successful life in, say, school; they are sent back to the actual world "undivinely discontented" (ibid., 38). For the experience is akin to the flattery of their egos or the process of putting themselves on the pedestal. But the other wish for fairy world is very different from this experience. No child really longs for all the dangers and discomforts of a fairy story but he or she is stirred and troubled by fairy land "with the dim sense of something beyond his reach"; the children return to the actual world "happy in the very fact of desiring". For the experience is "a special kind of longing" for fairy land which gives actual world a new and deeper dimension or makes it "a little enchanted" (ibid., p. 38). Instead of being preoccupied with themselves, as it is often the case of the more realistic stories, children are introduced to "permanent object of contemplation" through a great myth or fantasy and it enlarges their being by the mediation of "a thing of inexhaustible value" (Kilby 1964, 83).

It was Tolkien and Dyson who shared the reverence for myth, romance and fairy tale with Lewis, showed him that "mythology reveals its own kind of truth" (Downing 2002, 147) and myth was better understood as "a real though unfocused gleam of divine truth falling on human imagination" (Lewis 1960a, 139). Especially Tolkien, the writer of "The lord of the rings", made one of the most significant contributions to the subject of myth or fantasy literature through his Andrew Lang Lecture at St Andrews University, "On fairy stories". In this lecture, he put forward his basic ideas regarding imagination, fantasy, and subcreation while suggesting the three structural features of good fairy tales: recovery, escape, and consolation. In effect, Lewis's mythopoeia or myth-making and fantasy creation seemed to develop in dialogue with these three features. Of more direct relevance, Tolkien suggested that we most fully exercise our function as a "subcreator" of a subordinate world of our own in fairy stories which Lewis argued liberate human being's Archetypes in Jung's terms and teach us to obey the old adage "Know thyself", which has a direct bearing on the formation of young learners $(1966,36)$.

\section{Three features of good myth}

\section{Recovery}

This aspect of mythopoeia refers to "the restoration of a true view of the meaning of ordinary and humble things that make up human life and reality, things like love, thought, trees, hills, and food" (Duriez 2003, 71-72). In other words, it acknowledges that myths intend to restore the true nature of all earthly things in the world. For Lewis, the major function of imaginative world is a richer understanding of the realities of the world rather than the apprehension of concepts (Duriez 2000, 204). Lewis $(1966,90)$ gave a vivid flavour to this function of the myth when he wrote about the Tolkien's The lord of the rings, a radical instance of subcreation. Myth or fairy story restores to the familiar things their rich significance which has been veiled by familiarity as in the following examples:

The child enjoys his cold meat (otherwise dull to him) by pretending it is buffalo, just killed with his own bow and arrow. And the child is wise. The real meat comes back to him more savoury for having been dipped in a story; you might say that only then is it the real meat. If you are tired of the real landscape, look at it in a mirror. By 
putting bread, gold, horse, apple, or the very roads into a myth, we do not retreat from reality: we rediscover it.

Furthermore, Lewis highlights the powerful role that the fantastic imagery represented by a never-ending fairy land plays in restoring the true value of an individual human being in Tolkien's literary world. The reality of men's life which has "mythical and heroic quality" cannot be fully understood without using imagined "visible souls" which have "their insides and the outsides" (ibid., p. 89). "Character delineation" which would be done in a realistic work is replaced by the creation of dramatic characters such as a hobbit, a dwarf, or an elf in Tolkien's work. In effect, Lewis brought home the point that nowhere is the heroic nature of man to be represented more vividly and effectively than in a fairy story. These ideas were embedded in the plot and characterisation of The chronicles of Narnia.

All the children characters in the Narnia were just ordinary school boys and girls, not significantly less or more than other children, but they happened to achieve great feats in the Narnia world through various adventures and hardships, which would change their selfconcepts with a great potential to make a difference in their own world. Take Digory in The magician's nephew for instance. It was natural that the Queen Jadis said to him: "You? But you are only a child, a common child. Anyone can see at a glance that you have no drop of royal or noble blood in your veins. How did such as you dare to enter this house?" $(1955,62-$ 63). However, this seeming commonness or ordinariness of Digory has a significant bearing on Lewis's self-concept because Digory was closest to Lewis himself among all the children characters in the Narnia and would grow up to be the Professor Kirke in The lion, the witch and the wardrobe (Gray 1997, 150). He seemed to believe that he was as ordinary a man as Digory, but he also believed in the connection between ordinary reality and imaginative creation about which he had been on the defensive (Duriez 2000, 145). Lewis once said of The wind in the willows, a popular children's story written by Kenneth Graham (Lewis 1966, 14): "The happiness which it presents to us is in fact full of the simplest and most attainable things - food, sleep, exercise, friendship, the face of nature, even (in a sense) religion." After the aesthetic experiences of the reality of the real world being deepened by fantasy or fairy story, young learners are expected to be changed or restored to better persons as Lewis and Digory in their respective lives. This scenario was also true of Scrubb or Eustace in The silver chair. Pole or Jill has noticed the change in his attitude and behavior. Since his adventures in Narnia (described in The voyage and the Dawn Treader), Eustace was transformed into a completely different person. He stands up to the school bullies instead of supporting them, as is often the case.

This restorative aspect of fairy story is more germane to Lewis's understanding of the ordinary and earthly which was seen as the basis of spirituality $(1966,145)$. He learned this aspect from his spiritual mentor, George MacDonald whose stories are dominated by a joyful quality of holiness or goodness in life, which is set apart from platonic spirituality. The homely and ordinary which had been transformed by a new light were the essentials of MacDonald's stories. Lewis captured this aspect when he wrote about them: "The quality which had enchanted me in his imaginative works turned out to be the quality of the real universe, the divine, magical, terrifying and ecstatic reality in which we all live" (1947, xxxiv). This in turn shows that Lewis's imaginative world is also based on the humble and common things of life, "the quiet fullness of ordinary nature" (Duriez 2000, 145).

\section{Escape}


This aspect of mythopoeia refers to "escape from one's narrow and distorted view of reality and meaning - the escape of the prisoner rather than the flight of the deserter" (Duriez 2003, 72). In other words, it has a direct bearing on the escape from the dominion of darkness. Tolkien made remarkable distinction between "the escape of the prisoner" and "the flight of the deserter" in On fairy stories (Tolkien 1966) to defend the fantasy literature against the accusation of escapism. Escape from a real duty like a deserter is categorically bad, but escape from prison is not wrong. In effect, escape is by no means a dirty word. Its meaning is totally contingent on its following phrase, 'from what'. If you have a metaphorical sense of this word, it should rather be encouraged and promoted, not least because there have been lots of metaphorical prisons throughout the ages such as ignorance, materialism, dictatorship, religious fanaticism. Thus, if you are to do justice to the word, escape, you have to take note of wrong cases such as "Escape from reason" (Shaeffer 2006) or "Escape from freedom" (Fromm 1941).

Lewis made as strong a case about this accusation of escapism against mythopoeia as Tolkien. In a general sense, all of Narnia awaits deliverance from the dominion of the White Witch. The land itself longs to be free from captivity - to return to the peace and joy and beauty of the life it once knew. It is also a story of personal salvation - and the personal sacrifice that makes that salvation possible. In The lion, the witch and the wardrobe, Edmund falls under the spell of the White Witch and made a secret and dangerous alliance with her. He succumbs to his own pride, selfishness, greed, and lust. He becomes a traitor. And according to the Deep Magic (or law) on which Narnia was founded, Edmund must pay the penalty with his life (Ditchfield 2003, 46, 53). Escape from ignorance, religious superstition, and fear is one of the major themes of The horse and his boy. Calormen where Shasta lives has held its citizens captive in darkness. They live in a culture of both physical and spiritual slavery. The masses struggle with an overwhelming sense of hopelessness; the elite are obsessed with greed, lust, and the pursuit of power. Thus, Shasta and Aravis made their escape out of Calormen to Narnia which is a kingdom of light. Its citizens exult in their freedom. They are motivated by a sense of right and wrong, and a respect for others (i.e. the Tao). They prize personal honour and integrity. In Narnia, mercy and justice meet. It is a nation under Creator. So when Shasta and Aravis make their escape from Calormen to Narnia, in a very real sense they are moving from darkness to light, from death to light (ibid., 76). Just as Hooper indicates, Lewis's significant contribution to the liberation of many people from literary gaolers was interrelated to his familiarity with "the interior of the gaol-house from his own earlier imprisonment" (Lewis 1966, x).

It is through the grasping and following of the Tao, the universal moral laws, that human beings find their way to liberation from various sorts of tyrants. Sometimes they have been called natural laws, but they have nothing to do with the concept of "Great Mother Nature" who "eliminates the unfit", "decrees, purposes, warns, punishes, and consoles" as the potent agent to execute the principle of the survival of the fittest (Lewis 1960b, 41-42). On the contrary, the laws have been called "natural" because they have a significant bearing on human nature. They are rooted in the analysis of human nature which has considerable points of commonality across cultures, centuries, and continents. That humans have shared these universal laws may stand as a powerful reasoning behind the argument that human beings are not the offspring of nature which is marked by the law of "survival of the fittest". Lewis insisted that nature is not our mother but our sister because she and we alike were created by the supernatural Creator. As a corollary, we must not live by her principles but our laws. No one in the world is proud of claiming to obey the codes of their sister (Lewis 1986, 79). 
Lewis is resolute in upholding the moral and universal laws over anything else in the world, even the survival of class, culture, nation, and our species. All things in the world should be rooted in the natural or moral laws, and be obtained by respectable and benevolent methods, without which they will crumble to dust in the end. Since the human nature cannot invent a new law any more than create "a new primary colour" or "a new sun" or "a new sky", the human rebels with new ideas against the universal laws will destroy themselves at last. Lewis likened the situation to "a rebellion of the branches against the tree" $(1988,446)$.

\section{Consolation}

This aspect of mythopoeia refers to "consolation, leading to joy" $(2003,72)$, which is similar to the experience of intense longing for the supernatural world Lewis was to chart in Surprised by joy. It is a bedrock of Lewis's view of life and literature. Almost all his literary books and essays are imbued with this element, but nowhere is the most eloquent and persuasive argument made about this longing or joy than in The weight of glory (1980). He replaces the term of supernatural world with "our far-off country" (29), "the fatherland" (31), "Paradise" (33), "the far-off land" (33) or "beyond Nature" (44), and the term of longing or joy with "this desire for our far-off country" (29), "my desire for Paradise" (33), "your sense of exile in earth as it is" (31), or "your longing for the transtemporal" (32) in relation to the previous terms of supernatural world. This longing is "our spiritual longings" (39) in the sense that it is "a desire which no natural happiness will satisfy" (32). This longing is "our deep desire" which can be easily snuffed out by a simple remark to silence it (31). Nonetheless, it is "our lifelong nostalgia" (42) which we have cherished in this universe where "we are treated as strangers" (40).

Lewis points out that this intense longing or joy is different from other ordinary longings in two aspects. Firstly, unlike other desires whose satisfaction brings instant pleasure such as appetite, this longing "continued to be prized and even to be preferred to anything else in the world, by those who have once felt it" (Lewis 1933, 202). To them, this hunger or poverty is better than any other fullness or wealth. Secondly, when they feel the object of this desire, inexperienced people suppose that they know what they desire, like a child who may confuse some wishful thinking about a far-off place or an event in the past with the reality of reaching the place or experiencing the time of event. Even though the child can get access to the site or the event, he or she will get either nothing or the same desire will occurs again and again (203). The pilgrim's regress (Lewis 1933) aesthetically describes Lewis's spiritual exploration where he followed this desire, pursued the false objects until their falsity appeared, and then abandoned them. At last, he was able to get to "the clear knowledge that the human soul was made to enjoy some object that is never fully given - nay, cannot even be imagined as given - in our present mode of subjective and spatio-temporal experience" (ibid., 205).

As Lewis asserts many times in his works, that there is a longing for something indicates that something to quench the longing exists somewhere. Since you are thirsty, there must be water to quench your thirst. Since you long for truth, there must be a place "where you can taste it [truth] like honey and be embraced by it as by a bridegroom. Your thirst shall be quenched" $(1946,44)$. However, there have been many people who insist on the right of "the free play of enquiry" into truth based on abstract intellect, negating the possibility of final encounter with truth. They tend to interpret even this possibility as an encounter with "some ready-made truth which puts an end to intellectual activity" (ibid., 44). It is tantamount to claiming the 
freedom still to be dry while drinking water. He who regards a sensible enquirer into the finality of truth as childish is given a solid and confirmed counsel by the Spirit in The great divorce (44-45):

You have gone far wrong. Thirst was made for water; inquiry for truth. What you now call the free play of inquiry has neither more nor less to do with the ends for which intelligence was given you than masturbation has to do with marriage.

It is against the background of this sense of consolation that death functions as the common thread that runs through the Narnia and Lewis's imaginative writing (Gray 1997). Though death looks totally irrelevant to young learners who enjoy the prime time of life, they should be encouraged to reflect on the meaning of death and its relation to their present lives. No one in the world knows the proximity of death to their own lives. As such, death is not foreign to the children characters of the Narnia. Digory's (the personification of Lewis) dying mother was mentioned in the beginning of The magician's nephew, the 1st book of the Narnia in terms of the chronological order. In the same vein, The last battle, its last book, presupposes the death of the children marked by a train crash: "Your father and mother and all of you are as you used to call it in the Shadowlands - dead. The term is over: the holidays have begun. The dream is ended: this is the morning" (Lewis 1956, 228). In relation to their death, Lewis brings forth his own worldview on death and the life after it. For him, death is the beginning of a new heavenly world in which a totally different set of experiences will unfold under the most beautiful and best circumstances more than we can imagine. Parents may be opposed to the idea of presenting the concept of death to their children in school, because they "do not wish children to be frightened". Lewis $(1966,39)$ responded to them with an argument that this attitude of parents "would indeed be to give children a false impression and feed them on escapism in the bad sense." It was a ludicrous thing to Lewis to educate the generation exposed to terrorist attacks and the atomic bomb without referring to "a world of death, violence, wounds, adventure, heroism and cowardice, good and evil." Since young learners will face "cruel enemies" in their lives, it is better for them to hear of "brave knights and heroic courage."

\section{Pedagogical implications}

\section{Inculcate a right perspective on reading literature}

Tolkien posits that when a fantasy writer creates a Secondary World which may be "like" the Primary World (i.e., the world of ordinary waking reality), the Secondary World has its own literary or aesthetic reality (1966). This suggestion has a direct bearing on Lewis's stance towards readers' task as well as their delight: to enter the world with open eyes, accept it on its own merit, learn its rules and see it function (1961). Readers should not allow their own worldview to frustrate or impede a story; instead, they must "receive" rather than "use" a story (ibid., 93). This is keeping in line with Sire (1978) who sounds the alarm that when we appreciate imaginative literature such as fiction and poetry, utilitarian reasons such as promoting social status or searching for a philosophy of life should not come to the fore. Rather it should be acknowledged that "each piece of literature has its own reason for being, its own Secondary World. That comes first in order of priority as we read" (167).

This suggestion has much to do with the issue of understanding the Secondary World created by literary authors. To readers, what the Narnian stories may suggest about life as it is outside the stories does not carry much weight in the process of understanding the Secondary World. 
Since the stories "must first function on the story level, the level of the Secondary World", readers should first give themselves up to the stories in order to learn that Secondary World (ibid, p. 94). Contrary to the expectation of those parents who have some reservations about letting their children read the Narnia because of its allegorical meanings attached to Christianity, however, Lewis's Narnia as the Secondary World primarily originated from "a picture of a Faun carrying an umbrella and parcels in a snowy wood" (1966, 53), not from his intention or preconception to create Christ for children. Nature has been the first inspiration for images that Lewis could create for his own novels, because "Lewis saw nature as the creation of God, which reflects God's original design” (Greggersen 2003, 121).

In a process where the Secondary World is mediated by an image of nature, Lewis subcreated the Narnia where Aslan (Turkish for "lion") is depicted as the creator and ultimate sovereign of the land. It is natural that the creator or absolute ruler happened to be a lion, not least because it has been "a traditional image of authority". Set against this backdrop, Lewis's subsequent plan to make Aslan a symbol of Christ does not matter much to readers, because it is not Christ "as he appeared and will appear in our world (as a real man), but as he appears in Narnia (as a 'real' Narnian talking lion)" (Duriez, 2000, 23). In other words, Aslan is not Christ but a Christ figure that has been represented as a sacrificial saviour by many characters in different genres of literary world. Frodo Baggins in The lord of the rings, Harry Potter in Harry Potter series (fantasies), Santiago in The old man and the sea, Simon in The lord of the flies (novels), Randle Patrick McMurphy in One flew over the cuckoo's nest (films) or Clark Kent in Superman (comic books), to name a few. Readers of the Narnia are as deeply moved by the sacrificial and noble character of Aslan as other readers of other genres of literature by other Christ figures. Furthermore, the Christ figure is an indispensable element readily found in many myth stories throughout history, especially "scattered through the heathen religions all over the world - but still quite vague and mythical - the idea of a god who is killed and broken and then comes to life again" (1970, 58). This element transcends every culture, continent, and century. On top of that, Lewis's acknowledgment of these myths serves to underscore his concern about the interrelatedness of every religion in the world. He is known as a Christian author who did not negate other religious systems but put a great value on every religion found all over the world as a source which revealed the divine light in one way or another (1970). It was in the Narnia that all kinds of diverse traditions, cultures, and religions were beautifully and seamlessly blended into a universal fantasy designed for the delight and joy of readers.

Just as Kuteeva $(2000,279)$ illustrated, Lewis's unoriginality, "rewriting of the mythological tradition", had many forms in the Naria world, drawing on the following myriad traditions and myths from different cultures and ages throughout the world:

The account of Narnian creation: Genesis, Ovid, Lucretius, and Milton;

The scene of Aslan's sacrifice: A setting of pagan mysteries: the stone knife and the Stone Table, similar to Celtic cromlechs;

The hose and his boy: A peculiar admixture of characters and motifs deriving from Arabian, Babynonian, Greek, Roman, Celtic, and Norse tales;

Prince Caspian: $\quad$ The arrival of Bacchus with Maenads and Silenus, and ecstatic dance reminding of Greek Dionisias (Bacchanalias in Rome);

The voyage of the Dawn Treader: The tradition of the Irish immram; 
The silver chair:

The last battle: a popular motif of underworld journey into the Green Witch, a Narnian Persephone;

The images of Revelation and Ragnarök.

\section{Promote the Tao}

In this multicultural world, many kinds of cultural heritage and traditions are competing with each other in the multicultural classes all over the world. On many occasions, however, some minority students who have different cultural heritage from the majority students are seen to be harassed and bullied by the latter group. This problem cannot be solved by the democratic principles only, not least because they privilege majority rule over any other tenets. Seemingly it emboldens the majority students to do anything deemed favourable to their own interests, justifying their actions under the cloak of democracy. For instance, a student who has certain religious faith can be bullied by the majority students who believe in a major religion in their society, whatever religion it is.

What makes this matter more serious is the aspect that these majority students' behaviours and attitudes toward minority group of students may reflect the influence of their parents and teachers steeped in a certain religious faith. As Lewis (1970) noted, the school children are the product of the previous generation such as their parents and teachers. They are supposed to influence their children at home and school just as much as who they are. As the mainstay of their children's education, parents teach their children while being faithful to themselves in terms of worldview, religious faith, and values. With this in mind, Lewis gave a warning note to the superior or patronizing attitude which teachers or parents assume when they teach moral values to young learners. They should be treated as equal partners with whom teachers and parents readily share the same human experiences in the world, not an age group to be handled as a target raw material. It is only when they are treated with respect that teachers and parents can do them good with whatever stories $(1966,42)$. This aspect is closely linked to his suggestion that authors of children stories should present to children their own moral based on "whatever spiritual roots you have succeeded in striking during the whole course of your life", not "a platitude, or even a falsehood, skimmed from the surface of your consciousness" (41). Adults and children should meet each other as man to man or "independent personalities" (42).

Now, to which ethical system does our education have to resort in the multicultural world of education? There have been many people or groups of people which claimed to provide us with "new" or "scientific" or "modern" moralities to date (Lewis 1967, 75), but Lewis denies that we can have any authority to create a new moral system, likening the attempt to the one to invent a new sun or a new colour. His denial is based on the argument that there have been "the traditional precepts" or "the world-wide code" (i.e., the Tao) across cultures, religions, and generations. Thus, if any of them is to be denied or invalidated, other of them, not of a new moral system, should be presented as the rationale for the denial (53). Lewis's position should not be misconstrued as coming from his religious faith. On the contrary, he made it clear that his religion "is not a promulgation of a moral discovery" (46). Even his religion was predicated on the traditional morality, whose "ultimate ethical injunctions have always been premises, never conclusions" (ibid, 55). To make his point, Lewis referred to Kant who asserted that "the imperative is categorical", indicating that no argument can lead us to the ethical codes unless they are assumed as foundational truths (ibid, 56). In this sense, "unless we return to the crude and nursery-like belief in objective values, we perish" (ibid, p. 81). If you think that this statement is out of touch with the real situations, suffice it to say to refer to 
the Third Reich or Japanese colonial government which incurred a catastrophic damage to humankind before and during the Second World War. What if Germans and Japanese had said that anything could be justice so long as it were of a benefit to them? We cannot call them wrong and their ideology despicable "unless there is some objective standard of good, over-arching Germans, Japanese and ourselves alike whether any of us obey it or no" (73).

\section{Build up young learner's self-concept}

Aforementioned ideas can be represented by the following figure 1, which incorporates the mythopoeic dimensions (i.e., recovery, escape, and consolation) and their further manifestations in human formation (i.e., earthly beauty, Tao-based justice, and heavenly hope) into the self-concept elements (i.e., self-image, self-esteem, and self-ideal proposed by Tracy 2011). The recovery dimension is to reveal the true nature of all the ordinary and earthly in human life which primarily include the natural environment, humdrum everyday experiences, and interactions with other people. This dimension will not be complete without the restoration of the core agent in the process of recovery, i.e., young learners themselves. The self-image of each young learner should be restored to their unadulterated state which shines out for everyone to take a glimpse at their divine and spiritual entity. The escape dimension is to be free from the bondage of sinister world (e.g., Calormen) which is gripped by materialism, dictatorship, and religious superstition and return to the dominion of light (e.g., Narnia) which is governed by the Tao. The universal principles of the Tao best meet the urgent needs of young learners, i.e., how they can feel accepted and respected by others. When they acknowledge that every human does not only receive, but merit their respect, based on Tao, they will become increasingly aware of the legitimacy to respect themselves as well as others. The consolation dimension is to find solace in the unquenchable or inconsolable longing or joy for heaven or "home". This supernatural destiny prepared for young learners will be able to shed light on the basis of their self-ideal, i.e. the person they would like most to become.

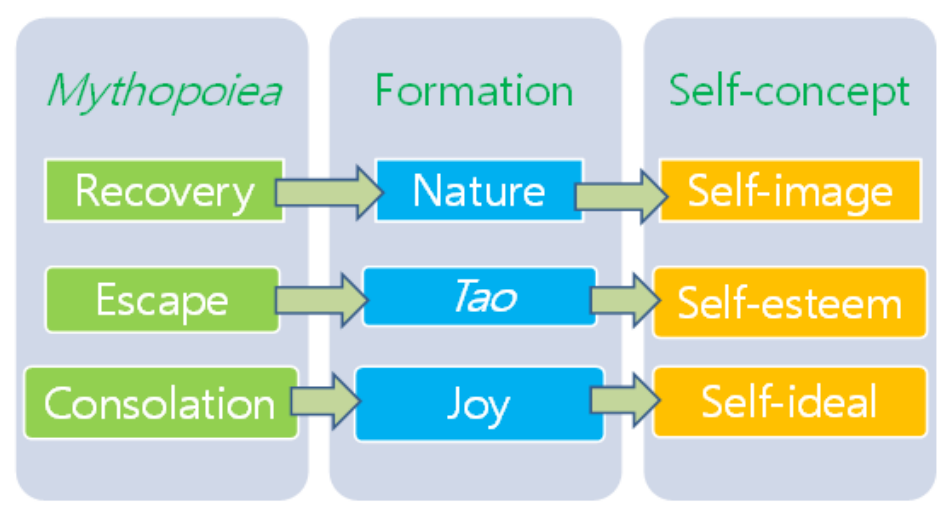

Figure 1. Conceptual framework of mythopoeia for the formation of self-concept.

When Lewis wrote the Narnia, he felt a great delight in imagining and creating "a happily inclusive world in which rational beings of widely varying kinds could live together, work together, and, when necessary, fight side by side for the good" (Chronicle of Higher Education, December 2, 2005). The inclusive nature of the Narnia also makes an important connection between heaven and earth, as Wright $(2008,115)$ posits: "C. S. Lewis ... did a great job in the Narnia stories and elsewhere of imaging how two worlds could relate and interlock." It will be a greatly heartening message for young learners that Creator's space and human's space are not far away, though very different, from each other in the present, and 
finally will be joined together in a phenomenally new way in order to be married forever (ibid., 116). In effect, the link between heaven and earth has been the primary point of focus in Lewis's mythopoeia. The message of "Beauty" which reflects the creative and imaginative aspects of human faculty, the pursuit of "Justice" which is based on the Tao, and the longing for "Hope" which is grounded in the supernatural realities of the new multicultural world where heaven and earth will join together, are the primary aspects that need to be enlightened to the eyes of, and internalized into the hearts of, multicultural young learners so that they can become spearheads for the beautiful, just, and hopeful world (ibid.).

\section{References}

Bolles, R. N. 2013. What color is your parachute? 2013: A practical manual for job-hunters and career-changers. New York: Ten Speed Press.

Carpenter, H. 1977. J. R. R. Tolkien: A biography. London: George Allen \& Unwin.

Ditchfield, C. 2003. A family guide to Narnia: Biblical truths in C. S. Lewis's The chronicles of Narnia. Wheaton: Crossway Books.

Downing, D.C. 2002. The most reluctant convert. Downers Grove: InterVarsity Press.

Duriez, C. 2000. The C. S. Lewis encyclopedia. Wheaton: Crossway Books.

Duriez, C. 2003. J. R. R. Tolkien and C. S. Lewis: The story of a friendship. Stroud: Sutton.

Fromm. E. S. 1941. Escape from freedom. New York: Henry Holt and Company.

Gray. W. 1997. Death, myth and reality in C.S. Lewis. Journal of Beliefs and Values 18, no. 2: $147-154$.

Greggersen, G. 2003. C. S. Lewis and the rejection of the Tao. Dialog: A Journal of Theology 42, no. 2: $120-125$.

Kilby, C. S. 1964. The Christian world of C. S. Lewis. Grand Rapids: Eerdmans.

Kilby, C. S. 1984. Holiness in the life of C. S. Lewis. Discipleship Journal 22: 14-16.

Kreeft, P. 1994. The shadow-lands of C. S. Lewis. San Francisco: Ignatius Press.

Kuteeva, M. 2000. Myth. In Reading the classics with C. S. Lewis, ed. T. L. Martin, 265-284. Grand Rapids: Baker Academic.

Lewis, C.S. 1933. The pilgrim's regress. Grand Rapids: Eerdmans.

Lewis, C.S. 1946. The great divorce. New York: Touchstone.

Lewis, C.S. 1947. George MacDonald: An anthology. New York: Touchstone.

Lewis, C.S. 1950. The lion, the witch and the wardrobe. New York: HarperCollins.

Lewis, C.S. 1951. Prince Caspian. New York: HarperCollins.

Lewis, C.S. 1952. The voyage of the dawn treader. New York: HarperCollins.

Lewis, C.S. 1953. The silver chair. New York: HarperCollins.

Lewis, C.S. 1954. The horse and his boy. New York: HarperCollins.

Lewis, C.S. 1955. The magician's nephew. New York: HarperCollins.

Lewis, C.S. 1956. The last battle. New York: HarperCollins.

Lewis, C.S. 1960a. Miracles. New York: Touchstone.

Lewis, C.S. 1960b. Studies in words. Cambridge: Cambridge University Press.

Lewis, C.S. 1961. An experiment in criticism. Cambridge: Cambridge University Press.

Lewis, C.S. 1962. The problem of pain. New York: Macmillan.

Lewis, C.S. 1964. The discarded image: An introduction to medieval and Renaissance literature. Cambridge: Cambridge University Press.

Lewis, C.S. 1966. On stories: And other essays on literature. Orlando: Harcourt Inc.

Lewis, C.S. 1967. Christian reflections. Grand Rapids: Eerdmans.

Lewis, C.S. 1970. God in the dock. Grand Rapids: Eerdmans.

Lewis, C.S. 1980. The weight of glory. New York: HarperCollins.

Lewis, C.S. 1981. Mere Christianity. New York: Macmillan. 
Lewis, C.S. 1986. Present Concerns. Orlando: Harcourt Inc.

Lewis, C.S. 1988. The abolition of man. In The essential C. S. Lewis, ed. L. W. Dorsett, 428466. New York: Macmillan.

Lewis, W.H., ed. 1966. Letters of C. S. Lewis. Glasgow: Harper Collins.

Lief, J. 2009. Challenging the objectivist paradigm: Teaching biblical theology with J.R.R.

Tolkien, C.S. Lewis, and Guillermo del Toro. Teaching Theology and Religion 12, no. 4: 321-332.

Lindsley, A. 2005. C. S. Lewis's case for Christ. Downers Grove: InterVarsity Press.

Pike, M. 2011. Ethical English teaching: Learning democratic values or living by the Tao? Changing English: Studies in Culture and Education 18, no.4: 351-359.

Shaeffer, F.A. 2006. Escape from reason. Downers Grove: InterVarsity Press.

Sire, J. 1978. How to read slowly: A Christian guide to reading with the mind. Downers Grove: InterVarsity Press.

Tolkien, J.R.R. 1966. The Tolkien reader. New York: Ballantine Books.

Tracy, B. 2011. Full engagement!: Inspire, motivate, and bring out the best in your people. New York: AMACOM.

Wellek, R., and Warren, A. 1956. Theory of literature. Harmondsworth: Penguin Books.

Wright, N.T. 2008. Surprised by hope: Rethinking heaven, the resurrection, and the mission of the church. New York: HarperCollins. 